\title{
DEL DERECHO DE QUIEBRA AL DERECHO CONCURSAL MODERNO $Y$ LA LEY DE REESTRUCTURACIÓN EMPRESARIAL
}

\author{
Alfredo Ferrero Diez Canseco
}

Los juristas entienden que existe una situación concursal cuando un deudor se revela imposibilitado de pagar a la pluralidad de sus acreedores, lo que exige establecer normas especiales para la protección de todos los intereses en presencia ${ }^{1}$. Esta situación exige crear y luego organizar una comunidad de pérdidas entre todos los acreedores, a pesar de que los interesados individualmente podrían convenir lo mejor para sus intereses; sin embargo, la situación concursal implica una pluralidad de intereses. Históricamente, las corporaciones de mercaderes (llámense Cámaras de Comercio, primero) y el Estado han tenido que intervenir creando procedimientos para satisfacer a la pluralidad de deudores, objetivo que es imposible de cumplir si se deja en la libre iniciativa de cada acreedor el velar por sus intereses particulares.

El prestigioso jurista Francisco Vicent Chuliáa distingue dos grandes métodos en la regulación de los procedimientos concursales y que corresponden a distintas etapas históricas:

\section{a) Método del mercado}

En este método se admite a la quiebra como un sistema mediante el cual se produce la liquidación y reasignación de los recursos, y se concibe que todos los deudores son iguales entre sí al igual que los acreedores; en consecuencia, se establece un procedimiento general liquidatorio y judicial.

1 VICENT CHULIÁ, Francisco, Compendio crítico de Derecho Mercantil, Librería Bosch, $2^{\text {a }}$ edición, 1986, tomo II, pág. 757.

2 Ibidem. pp. 757 - 758. 


\section{b) Método gubernativo}

Se caracteriza por la intervención de los poderes públicos, y se sustenta en la idea de que existe una fundamental desigualdad entre los deudores y los acreedores en el mercado debido a la existencia de intereses y situaciones distintas.

Las características de este método son las siguientes:

1)Es especial, es decir, aplicable a determinadas empresas;

2)Es conservativo, es decir que pretende la conservación de la empresa en lugar de su liquidación, entre otras razones porque entiende de la dificultad en la reasignación de recursos; y

3)Es administrativizado, es decir, con participación de los poderes públicos en cuanto a la adopción de medidas y toma de decisiones y a las facilidades que en algunos casos otorga para la obtención de recursos financieros.

\section{Antecedentes históricos}

El concepto de quiebra y las medidas utilizadas para el pago de deudas se han ido «humanizando» en el transcurso del tiempo. Si nos remontamos al derecho romano, el deudor respondía de sus obligaciones incluso con su vida y la libertad. El acreedor tenía derecho a encadenarlo en sus casa particular, a matarlo o a venderlo como esclavo, «trans Tiberim».

La «Ley Poetelia» marca el tránsito del sistema de ejecución personal, ejecución sobre la persona del deudor (manus iniectio), al sistema de ejecucion patrimonial (non corpus debitoris sed bona obnoxia) mediante el cual los acreedores son puestos en posesion de todo el patrimonio del deudor que ha sido condenado, o que ha confesado sus deudas, o que no ha comparecido a la causa ${ }^{3}$.

3 Ibidem, p. 758. 
En sus orígenes y en el derecho romano el procedimiento en caso de insolvencia era un procedimiento de autodefensa dirigido por los mismos acreedores. Más adelante, en el derecho francés y el estatutario italiano aparece el principio publicístico como consecuencia del rigor que va a caracterizar a las legislaciones de quiebras, partiéndose de la idea de que el quebrado es un defraudador ${ }^{4}$ y que al Estado de interesa reprimir el hecho ilícito o delictivo como finalidad que va unida a la satisfacción de los acreedores. Incluso podríamos afirmar que la sanción era tan importante para la ley, que se descuidaba el interés de los acreedores, quienes muchas veces se perjudicaban con el procedimiento establecido.

El derecho concursal, más conocido como derecho de quiebras, irá evolucionando; aparecerá la institución de la masa de acreedores como la colectividad que se somete al principio de igualdad de trato; surgirá la acción revocatoria o pauliana para impugnar las ventas anteriores hechas fraudulentamente en perjuicio de los acreedores, y paulatinamente los mecanismos para garantizar el cumplimiento de las obligaciones por parte del deudor irán distinguiendo los derechos personales y civiles de las obligaciones patrimoniales; aparecerá igualmente la graduación de créditos, distinguiéndose éstos en privilegiados, hipotecarios y comunes.

A pesar de estos avances en la concepción de los derechos civiles y patrimoniales en el derecho de quiebras, aún en los siglos XIII y XIV la quiebra supuso añadir al régimen común de la cesión de los bienes un régimen de ejecución-represión, para forzar al quebrado a manifestar al quebrador posibles bienes ocultos. Es más, en los estatutos de algunas ciudades italianas se añadía el tormento como sanción, además de la inhabilitación para ejercer el comercio y otras profesiones.

La doctrina y los juristas reconocen a las Ordenanzas de Bilbao como una de las primeras reglamentaciones completas acerca de la quiebra, tanto en el aspecto procesal (intervención de la correspondencia, nombramiento de depositario, inventario, presentación de balances), como en el aspecto material (disposición e integración de la masa, retroacción, acción pauliana, etc.).

4 Garrigues, Joaquín, Curso de Derecho Mercantil, Editorial Porrúa, 1981, tomo II, p. 379. 


\subsection{El deudor civil y el deudor comerciante}

Un antecedente histórico importante de anotar en el derecho de quiebras del siglo XIX, es que siguiendo la tradición de las Ordenanzas de Bilbao y la doctrina de los antiguos tratadistas, la quiebra se regulaba como una institución propia y exclusiva de los comerciantes. El día de hoy, en la mayoría de las legislaciones, si no en todas, esta distinción entre deudor civil y comerciante ha desaparecido. La diferencia radicaba, por ejemplo, para el caso de España, en que para los no comerciantes se resucitaba el antiguo concepto de «concurso», donde aparece la cesión de bienes a los acreedores bajo la forma de juicio voluntario: el juicio se promovía por el mismo deudor cediendo todos los bienes a sus acreedores. El comerciante era tratado con mayor severidad; esta severidad la podemos comprobar en el hecho de que el quebrado tenía la sanción de prisión en caso de que la quiebra se tipificase en determinada forma. Existían además sanciones penales ligadas a la quiebra fraudulenta.

Para que fuera declarada la quiebra bastaba el sobreseimiento en el pago de las obligaciones, siempre que fuera indicio de insolvencia. Para el concurso se necesitaba la comprobación de la insuficiencia patrimonial del deudor acreditada en el hecho de no haber encontrado bienes libres en las situaciones aisladas. Es decir, en un caso, quiebra, nos referimos a indicio de insolvencia, y en el otro, concurso, se exigía la comprobación de insuficiencia patrimonial. Tal y como se ha mencionado, actualmente se reconoce la conveniencia de unificar los procedimientos de quiebra y de concurso de acreedores, eliminando la distinción entre quebrado comerciante y quebrado civil. La explicación que se puede dar a la existencia de esta distinción y a la mayor severidad con que se trataba al comerciante se sustentaba en la mayor trascendencia de las quiebras mercantiles.

En el Código de Comercio francés de 1807, el comerciante era objeto de arrestos y se le aplicaba amonestaciones penales por la realización de conductas típicas - por ejemplo en el caso de que los gastos personales fueran injustificados-, pudiendo incluso ser sancionados con la pérdida de sus derechos civiles y políticos hasta su rehabilitación, la misma que se condicionaba al pago de las deudas.

\footnotetext{
5 Ibídem, p. 381.
} 
Otro problema que surgía en el derecho de quiebras es el relativo a los bienes adquiridos por el cónyuge del comerciante. De acuerdo con la presunción muciana de la quiebra, se presumía que todos estos bienes los habían adquirido con el beneficio del comercio y por lo tanto eran incluidos en la masa de la quiebra, salvo prueba en contrario del cónyuge propietario de los mismos. Incluso los bienes dotales y privativos de la mujer, pero administrados por el marido, también eran objeto de ejecución, salvo que se hubiera publicado en el registro mercantil la escritura pública de la entrega ${ }^{6}$.

\subsection{Incumplimiento, cesación de pagos e insolvencia}

Los juristas han sido muy extensos en la discusión respecto de cuáles deberían ser las causas de apertura de la quiebra. El derecho romano se refería a la insuficiencia patrimonial. Sin embargo, el tráfico mercantil de hoy, que se funda en el cumplimiento riguroso de las obligaciones, nos permite distinguir y afirmar que no toda insuficiencia patrimonial implica la quiebra. Es sumamente importante, para efectos de definir los presupuestos objetivos de la quiebra, diferenciar al incumplimiento de la insolvencia.

El Código francés establecía que todo comerciante que cesara su pago se encontraba en estado de quiebra. Sin embargo, esta fórmula no se ajusta a la realidad; la cesación de pago puede ser un hecho aislado y obedecer a un incumplimiento momentáneo o puede referirse a una obligación determinada con un acreedor singular. Será necesario determinar si esa cesación corresponde a una verdadera insolvencia y si ésta es transitoria o definitiva.

La insolvencia se refiere no sólo al deudor que no paga a ningún acreedor, sino también al que puede pagar a algunos dejando insatisfechos o impagos a otros, o al deudor que puede pagar todas sus deudas pero sólo parcialmente. Según Garrigues, sólo es admisible la ejecución universal o colectiva que provoca la quiebra cuando el deudor se encuentra en una situación patrimonial de insolvencia definitiva?.

6 Ver Vicent Chuliá, Francisco, op, cit., p. 761.

7 Ver Broseta Pont, Manuel, Manual de Derecho Mercantil, $8^{\mathrm{a}}$ edición, Editorial Tecnos S. A., 1990, p. 658. 
La insolvencia presupone una situación o estado patrimonial en el que el deudor no puede satisfacer a sus acreedores en el momento en que ellos pueden exigirle el cumplimiento de sus obligaciones. Puede y debe distinguirse entre la insolvencia provisional o transitoria, cuando el deudor no puede pagar debido a una situación de iliquidez a pesar de que el valor de sus bienes superan al de su deudas, y la insolvencia definitiva, que se presenta cuando el valor total de sus bienes es inferior al importe de sus deudas.

El problema se presenta al trata de determinar y probar esta insolvencia definitiva; pareciera que la única forma es mediante manifestaciones externas que sean de fácil comprobación, para lo cual los acreedores deberán justificar sus títulos de crédito, siendo necesaria la intervención del órgano jurisdiccional.

Al pretender definir la cesación de pagos se nos presenta, al igual que para el caso de la insolvencia, el problema de encontrar parámetros objetivos, y tendrá que decidirse atendiendo a hechos que la demuestren ya sea directa o indirectamente, como por ejemplo mediante la declaración pública de cesación de pagos, los protestos cambiarios, embargos, sentencias de condena y ejecuciones infructuosas. La dificultad se presenta, ya que, como se ha afirmado anteriormente, no toda cesación de pagos responde a una verdadera insolvencia. Definitivamente, la cesación de pagos podemos considerarla como un modo de manifestar la insolvencia, pero no es el único modo. La cesación de pagos, como lo manifiesta Garrigues ${ }^{8}$, ya no es causa de la quiebra, sino que es su efecto más importante. La cesación de pagos, por sí, no amerita abrir concurso, salvo que ésta se funde en una insolvencia verdadera y definitiva, debiendo ser el órgano jurisdiccional el encargado de apreciar si hay o no insolvencia que implique un estado de permanencia o definitivo que haga imposible el cumplimiento por parte del deudor.

Es posible afirmar entonces que no podremos hablar de insolvencia definitiva cuando el valor de ejecución del deudor supere el importe de sus deudas. Una falta transitoria de medios de pago no es causa suficiente para poder declarar la quiebra, ya que el comercio en general implica cierto riesgo y los comerciantes están expuestos a crisis, las que pueden ser resueltas

${ }^{8}$ Garrigues, Joaquín, op. cit., p. 387. 
acudiendo al crédito o intensificando la producción. Siempre y cuando la situación se pueda sanear y no se considere como permanente, no podríamos calificarla de insolvencia para efectos de derecho concursal. Mientras el deudor posea suficientes bienes como para pagar a los acreedores no estamos ante una verdadera insolvencia o imposibilidad patrimonial y pueden los acreedores tutelar sus derechos individuales por medio de acciones ejecutivas, también individuales. La complejidad y multiplicidad de intereses involucrados en el proceso de quiebras, nos indica que es prudente reservar el procedimiento concursal para los casos de verdadera insolvencia.

\subsubsection{La calificación de la insolvencia}

El tema de la insolvencia, la cesación de pagos y los incumplimientos nos lleva al tema de la calificación de la insolvencia o de la quiebra. Al lado del interés privado de satisfacer a los acreedores existe el interés público de determinar si la insolvencia ha perjudicado negligente o voluntariamente al crédito conseguido por los acreedores, o si con ella se ha cometido algún delito.

Antiguamente todo quebrado era fraudulento y contra esta presunción absoluta de fraude se fueron admitiendo pruebas en contrario, hasta llegar a distinguir entre la quiebra no culpable o fortuita y la culpable o bancarrota, que a su vez puede ser culpable o fraudulenta.

El Código de Comercio español vigente en el año 1981, establecía, aunque la regla general es que la quiebra culpable y el fraude no se presumen, presunciones objetivas de uno y otro lado con relación a la conducta del quebrado. La diferencia entre la quiebra culpable y fraudulenta residía básicamente en la intención del quebrado, pero sabemos bien que la probanza de la intencionalidad es sumamente complicada.

Para efectos del derecho concursal la quiebra fraudulenta tiene por objeto ya sea disimular el pasivo o simular el activo con el objetivo de disminuir la cuota de reparto entre los acreedores, con el consiguiente beneficio del deudor.

La legislación española enumeraba los hechos calificadores de la quiebra culpable que llevan inherentes una presunción legal de culpa, tales 
como: gastos excesivos, endeudamientos excesivos, pérdidas injustificadas, etcétera. Respecto a la quiebra fraudulenta la ley española exigía presunciones iure et de iure tales como la simulación o exageración del pasivo, la ocultación o reducción del activo, la falta de contabilidad y las irregularidades en la misma, el lanzamiento de bienes y pagos anticipados?.

Para efectos de determinar el estado de insolvencia, los distintos sistemas legales acogen una de estas alternativas:

1. Algunos enumeran expresamente los actos de quiebra.

2. Algunos establecen la cesación de pagos como manifestación de la insolvencia.

3. Para algunos los tribunales libremente, de acuerdo con su convicción, pueden determinar cuáles son los indicios de la insolvencia.

4. En otros la ley atiende al estado de desbalance sustentado en el hecho de que el pasivo supera al activo.

Las legislaciones latinas en general se han inspirado en la ley del sistema francés que fijaba la cesación de pago como situación de insolvencia; sin embargo, como lo hemos manifestado, la cesacion de pagos no siempre implica una insolvencia definitiva y permanente, motivo por el cual en la actualidad se entiende, como ya lo hemos afirmado, que más que la causa de la quiebra la cesación de pago es el efecto más importante de ésta. Es así que las legislaciones modernas están optando por otorgar al órgano jurisdiccional la facultad de determinar la insolvencia definitiva atendiendo a criterios objetivos de desbalance patrimonial, previo análisis técnico al respecto, sustentado en elementos objetivos que fija la legislación en la materia.

\section{II. ¿El nuevo derecho concursal?}

Francisco Vicent Chuliá, así como una gran mayoría de juristas ${ }^{10}$, se atreve a afirmar que existe una evolución hacia un derecho concursal moderno.

9 Garrigues, Joaquín. op. cit., pp. 397-398.

10 Vicent Chuliä, Francisco, op. cit., p. 764. 
Vicent Chuliá distingue hasta tres etapas en este derecho concursal moderno, partiendo de los siguientes conceptos:

- La quiebra inspirada en la idea de la liquidación colectiva, en la cual el convenio entre acreedor y deudor es un beneficio que se concedía al deudor en circunstancias muy concretas, basadas en la mayoría de las veces en su conducta personal. Ésta es la tendencia que podemos apreciar a fines del siglo XIX y principios del siglo XX.

- Entre la primera guerra mundial y la crisis industrial, podemos identificar una segunda etapa en la cual el legislador pretende facilitar el convenio entre deudor y acreedor, bajo el sustento del principio de conservación de la empresa.

- Se puede identificar una tercera etapa en el período que se inicia después de la segunda guerra mundial, en la cual se prioriza el interés público en la conservación de la empresa. Incluso la decisión del juez se impone a los particulares para aprobar un convenio serio, surgiendo la necesidad de recurrir al Estado con la finalidad de que participe en el proceso concursal. Responde esta concepción a la idea estatista que prevaleció a mediados de siglo y en adelante como respuesta a la desconfianza por un interés privado egoísta.

Actualmente podríamos afirmar que estamos ante una cuarta etapa en el desarrollo del derecho concursal moderno, en la cual el concepto de quiebra está en crisis y en donde ya algunos identifican el nuevo derecho concursal como el derecho de las empresas en dificultades, cuyas características y particularidades desarrollaremos en las siguientes páginas.

\subsection{La crisis del concepto de quiebra}

De la revisión de diversas legislaciones de este siglo, relativas al derecho de quiebras, se puede apreciar que el objetivo principal no aparece claro, como así lo reconocen los juristas. Consciente o inconscientemente todos los mecanismos del derecho concursal se dirigían a la sanción del quebrado. 
Actualmente el concepto de quiebra como mera sanción ha entrado en crisis, y esto se debe a que con frecuencia el proceso de la quiebra no es un instrumento social positivo, y no todo se reduce a la premisa que sostiene que el resarcimiento del daño nunca es total; existe una insatisfacción general por lo que la quiebra es y por la forma en que se realiza y éste es un tema que tiene que ver con la ideología de fondo del proceso.

Piero Pajardi, en un artículo publicado en la Revista de Derecho Comercial del año 1982, opina acertadamente que lo que estaría en juego es la quiebra como servicio social de justicia: si es que este proceso es útil o podemos convertirlo en algo útil, se le debe conservar; de otra forma, algunos postulan la conveniencia de integrarla al proceso ejecutivo individual ${ }^{11}$.

A efectos de analizar el proceso de quiebra, interesa no únicamente la naturaleza jurídica del proceso, sino también el resultado práctico y económico del mismo. Pareciera que a algunos legisladores no les ha importado si el acreedor realiza plenamente sus créditos, siendo esto totalmente eventual o aleatorio, condicionado a circunstancias de hecho extrañas a los intereses del proceso ${ }^{12}$. Los jueces, el legislador, el jurista e incluso el abogado, parecerían más preocupados muchas veces en el «debido proceso» como punto básico del derecho concursal, en vez de tratarlo como un valor relativo, como un factor metodologico, siendo que lo principal es la satisfacción de las partes y la supervivencia de la empresa. Sucede que los acreedores llegan incluso a no interesarse en la marcha del proceso de quiebra, ya que consideran que el ocuparse de él resultará en un daño ulterior por el tiempo perdido en relación al resultado que obtendrán. No postulamos tampoco que debemos simplemente despreocuparnos de la metodología formal. Lo que queremos afirmar es que tan importante o más que la metodología formal es la garantía del resultado económico del proceso concursal. No sólo es importante confeccionar leyes, sino que hay que adecuarlas a las técnicas organizativas necesarias para que sean útiles a la sociedad en su conjunto.

Jean Paillusseau en su artículo «Del derecho de la quiebra al derecho de las empresas en dificultades», citando a K. Cort afirma que el derecho de

"PAJARDi, Piero, «El proceso de quiebra entre el pasado y el futuro", Revista de Derecho Comercial, año 15, 1982, Ediciones Depalma. p. 182.

${ }^{12}$ Ibídem, p. 184. 
la quiebra está en quiebra y esto sucede y ha sucedido en forma general en Alemania, Japón e Inglaterra, a pesar de que algunos de estos países han modificado y promulgado la normativa pertinente, como en Estados Unidos el Bankrupctcy Act, que quedó codificado bajo el capítulo 11 del United States $\mathrm{Code}^{13}$. Sin embargo, las soluciones obtenidas luego de las modificaciones legislativas a las que se ha sometido el derecho concursal en el mundo, no son siempre satisfactorias. Tal vez lo que hay que cuestionar es la filosofía de fondo del derecho concursal y no simplemente su procedimiento y metodología.

\subsection{1 ¿Cuál es la causa del fracaso del derecho de quiebras?}

Creemos que una de las causas del fracaso del derecho de quiebra puede estar en el poco entendimiento que tienen algunos legisladores acerca de las realidades económicas y sociales del mundo moderno, lo que se refleja en algunos casos en un temor al cambio. También podríamos encontrar explicación de este fracaso en la falta de información que tiene el común de la gente acerca de cuál debe ser finalmente el objetivo y los intereses que defienden los procesos de quiebra.

Hemos visto cómo históricamente se le ha ido atribuyendo al «derecho de quiebra» diversas finalidades; una de éstas fue la sanción del deudor quebrado, otra fue la protección del crédito, y otra, la elaboración de un procedimiento de ejecución de los bienes del deudor. Estos tres, entre otros, son algunos de los principios que la doctrina asigna como los más comunes para sustentar las finalidades del derecho de quiebras.

Los acreedores se percataron de que sin una garantía no había esperanzas de pago y pretendieron todos substraerse del principio de igualdad, creando privilegios, tales como garantías reales y acciones directas contra los deudores de su deudor. Esto llevó a afirmar a más de un jurista y a preguntarse acerca de la autodestrucción del derecho concursal ${ }^{14}$. El derecho

${ }^{13}$ Palllusseau, Jean, «Del Derecho de la quiebra al Derecho de las empresas en dificultades», Revista de Derecho Comercial, año 17, 1981, Ediciones Depalma, p. 656.

${ }^{14}$ Ibidem, p. 658. 
de quiebras se tornaba en un procedimiento destinado a establecer el orden de los acreedores privilegiados, de los titulares de las garantías reales y a prever la concurrencia de los acreedores en la masa patrimonial. ¿Es que acaso los únicos intereses en juego son los intereses de los acreedores? ¿No tienen también interés en este procedimiento los trabajadores de la empresa, los proveedores, los clientes, las colectividades locales y el Estado? Creemos que sí, y cuanto más importante sea la empresa más numerosos y variados serán los intereses que su crisis pone en peligro.

Otra omisión de las legislaciones del derecho de quiebras está dada por la falta de un sistema por el cual sea posible detectar las dificultades con anterioridad a la quiebra y evitar que se declare ésta cuando ya hacía tiempo que la situación era cuando menos problemática. La pregunta es: ¿qué sistema de prevención es adecuado para que, por un lado, no se produzca una intervención injustificada a las empresas y, por otro lado, podamos salvaguardar los diversos intereses que circulan alrededor de una empresa? Lo real es que muchas veces cuando se declara la quiebra ya no solamente es muy difícil salvar a la empresa, sino que la liquidación de ésta no va a alcanzar ni siquiera a satisfacer a los acreedores privilegiados; más aún, la lentitud de los procedimientos agrava la situación y todo este proceso no podrá hacer otra cosa que dejar insatisfechos a todos o a la mayoría, encontrándose los acreedores forzados a aceptar soluciones y consintiendo en el financiamiento de situaciones desesperadas. En base a estos argumentos la doctrina propone que el derecho de quiebras debe ser replanteado en cuanto a las finalidades y objetivos. No significa esto que las finalidades originales dejen de tener vigencia, sino que estas finalidades originales deberán adecuarse a las nuevas realidades económicas actuales y se deberán sumar a las finalidades que plantea el derecho concursal moderno. La protección de los acreedores y de los créditos no puede ni debe descartar otros intereses y el interés general. Algunos como Paillusseau postulan que estamos en proceso de movernos de un derecho de quiebras a un derecho de las empresas en dificultades, donde la empresa sea la que ocupe el centro del nuevo derecho, porque finalmente si la empresa no está en crisis ninguno de los otros intereses está en peligro ${ }^{15}$.

${ }^{15}$ Ibidem, p. 660. 


\subsection{Hacia un nuevo derecho concursal}

El derecho concursal moderno, en síntesis, subordina el interés de los acreedores y el interés al resarcimiento vía sanción, al objetivo principal de maximizar el valor de la empresa en funcionamiento, con el objeto y fin de lograr la reactivación de la empresa. La liquidación y quiebra declarada de la empresa debe ser la última alternativa a la cual deberá acceder, ya sea el juez o las partes en conflicto interesadas.

Pero ¿por qué hablamos del derecho concursal moderno? ¿Tenemos acaso algunas pruebas concretas de que efectivamente este movimiento de reforma se está produciendo, o es simplemente que estamos convirtiendo en realidad lo que son simples deseos o buenas intenciones?

A efecto de sustentar esta nueva corriente, mencionaremos algunos ejemplos:

- Francia: El artículo primero de la ley del 25 de enero de 1985 da origen en Francia a un procedimiento judicial dirigido a permitir «la salvaguarda de la empresa, el mantenimiento de la actividad y del empleo y la satisfacción del pasivo» ${ }^{16}$. Esta definición es sumamente ilustrativa y presenta algunos elementos que nos permitirán distinguirla de lo que es y lo que era en general en las legislaciones del mundo el derecho de quiebra. Podemos apreciar cómo en este artículo de la ley comentada se reconoce con carácter general que la satisfacción de los acreedores no es ya la finalidad primordial de los procedimientos concursales; podremos más bien hablar cuando menos de un triple interés: trabajadores, acreedores y empresa. Según Emilio Beltrán, la ley francesa va más allá al afirmar que la empresa no será salvada y reflotada porque constituya el mejor modo para el pago de los créditos, sino que lo será a pesar y aun en contra de los acreedores del deudor ${ }^{17}$.

${ }^{16}$ Beltrán, Emilio, «El nuevo derecho concursal francés (La ley del 25 de enero de 1985 relativa al "Redressment" y la liquidación judicial de la empresa)», Revista de Derecho Comercial, año 18, 1985, Ediciones Depalma, p. 1.

${ }^{17}$ Ibídem, p. 1. 
- España ${ }^{18}$ : El decreto ley español del 20 de octubre de 1969, sobre administración judicial de empresas embargadas, cubre un vacío en el derecho concursal español, relacionado con la creación de un régimen de administración judicial a cargo de nuevos administradores designados por el juez, así como con la participación en la administración de los diversos interesados en la marcha de la empresa, es decir, acreedores, accionistas y trabajadores. Un aspecto interesante del dispositivo es que se consideraba objeto de embargo y administración a aquellos «grupos de empresas» cuyas acciones y participaciones representaran la mayoría del capital en una sociedad, y que por tanto tuvieran su control legal. Ésta y otras normas se promulgaron en España con el objeto de evitar la desaparición de empresas pertenecientes a sectores claves de la economía nacional, normas que les permitían la salvación y viabilidad económica a las empresas en crisis, lo que a su vez permitía que en la medida de lo posible se mantuvieran los puestos de trabajo.

Bajo este contexto, en el año 1978 en España se promulgó una legislación consistente en la concesión de créditos extraordinarios en cuanto a cuantía y condiciones, con vencimientos a largo plazo, con la idea de poder sostener un plan de saneamiento, reestructuración y reconversión.

El 5 de junio de 1981 se da una norma con carácter general relacionada con la reconversión industrial. Ésta fue sustituida por la ley de Reconversión y Reindustrialización del 26 de julio de 1984, que introduce en España importantes modificaciones en el régimen de las Sociedades Anónimas de Reconversión (S.A.R.), sistema al que se pueden someter las empresas acogidas a un plan de reconversión. El acogimiento del plan implicaba incluir en los estatutos sociales restricciones a la libre transmisibilidad de las acciones y el carácter nominativo de éstas, así como la participación de las autoridades estatales en los órganos de estas Sociedades anónimas de reconversion.

Las decisiones de los organos sociales, que afectaban el plan, deberían contar con la conformidad de la representación de la administración del Estado. Esta ley contenía, además, medidas de carácter tributario, financiero y

18 Ver Vicent Chuliá, Francisco, op. cit., pp. 766-776. 
laboral para empresas en crisis, siempre y cuando la recuperación de la empresa fuera de interés general y social.

En el ámbito laboral, por ejemplo, se implantaron algunas modificaciones para favorecer a estas empresas, y «el plan», para efectos laborales, era considerado causa tecnologica para la modificación, suspensión o extinción de las relaciones laborales, y para medidas de movilidad geográfica o funcional.

Estas empresas también tenían acceso al crédito oficial, al aval del Estado y a las subvenciones. Se establecieron créditos participativos con un tipo de interés fijo y a un plazo de amortización no inferior a los 15 años, siendo, los tres primeros, años de gracia. Estos créditos se denominaban así porque, entre otras características, a las entidades acreedoras, además del interés pactado, que era fijo, se les concedía participación en el beneficio neto del ejercicio.

Este conjunto de normas excepcionales, de naturaleza sustantiva y tributaria, se crearon con el objeto de ayudar a aquellas empresas que estaban en situación económica dificultosa, y se concedían con el objeto de transformar créditos preexistentes con una nueva financiación de carácter extraordinario.

Tanto para España como para Francia, es evidente el interés de la nueva legislación vinculada al derecho concursal --y de las normas accesorias a éste- por conservar a la empresa como ente economico de interés para la sociedad en su conjunto. Es importante reconocer que en España esta ley se debía a una coyuntura particular. Sin embargo, estas medidas marcaron una pauta de lo que podemos reconocer como un derecho concursal más preocupado en la reestructuración de la empresa que en la liquidación de su patrimonio.

\subsection{Principios inspiradores del nuevo derecho concursal}

Además de los principios tradicionales de igualdad entre los acreedores, universalidad patrimonial y comunidad de pérdidas, es necesario agregar otros principios que permitan concretar una reforma real en las legislaciones rela- 
tivas al derecho de quiebras y al derecho concursal, y en este aspecto es importante considerar los siguientes principios ${ }^{19}$ :

1. Prioridad del principio de conservación de la empresa, atendiendo a que los interesados no son sólo los acreedores, sino que hay un contexto social que también es importante salvaguardar (empleados, accionistas, etc.).

2. Insistencia en las medidas preventivas, sobre todo de información y control contable. Se requiere la introducción de medidas preventivas complementarias al derecho concursal, destinadas a prever y prevenir la crisis, definiendo además las funciones y responsabilidades de los auditores financieros, directores y administradores.

\section{Protección adecuada del crédito.}

4. Unidad de solución concursal, para el caso de insolvencia definiti$v a$, respecto de toda clase de deudores.

5. Amplitud del margen de decisión judicial para la declaración y disolución de la crisis. Incluso algunos postulan la actuación de oficio de los órganos jurisdiccionales y la anticipación de la declaración concursal, con el fin de no llegar demasiado tarde a poner remedio a la crisis.

6. Traslado de las responsabilidades de la prevención y saneamiento de las empresas a expertos auditores y economistas que aporten criterios técnicos para determinar el valor de la empresa en términos de conservación y alternativas a su liquidación.

Recordemos que el fin primordial es el saneamiento y no la liquidacion, siempre y cuando se analice con criterios técnicos que el valor de esa organización es superior al de la liquidación y que es posible un reparto equitativo de los costos de aquella organización entre todos los interesados.

7. Facilitación de la recuperación patrimonial del fallido de buena fe y la mayor severidad de trato para quienes hayan utilizado los medios legales para el abuso fraudulento del crédito.

19 Ver Alegría, Héctor, «Algunas bases para la reforma de la ley de Quiebra», Revista de Derecho Comercial, año 1970, Ediciones Depalma, p. 157. 
8. Extensión de la responsabilidad patrimonial frente a los terceros de buena fe, de quienes obraren por el deudor y realizaren en su beneficio actos que determinen, mediante el dolo o la infracción de las normas legales, el empobrecimiento intencional del deudor o su apariencia de insolvencia.

9. Internacionalización del concurso, superándose el concepto estricto de territorialidad del procedimiento y de las facultades de los administradores y de la masa concursal. El principio de la territorialidad del derecho concursal es anacrónico; esto lo podemos apreciar con mayor claridad en el caso de Europa, que hoy se organiza a través de la Comunidad Económica Europea. Ya se han producido y se van a seguir produciendo a lo largo de la historia numerosas quiebras internacionales que es necesario prever, creando los mecanismos necesarios para que los acreedores no se vean desamparados. Respecto de las facultades de los administradores y su responsabilidad, se extenderá el comentario al analizar los aspectos preventivos en el siguiente capítulo.

\subsection{Reseña de aspectos sustantivos y procesales del derecho concursal moderno que merecen nuestra atención}

\subsubsection{Insolvencia o cesación de pagos}

Como fórmula genérica, ya hemos visto que es preferible adoptar el criterio de insolvencia y no el de simple cesación de pagos, evitando, pues, que se vincule el mero incumplimiento con la apertura del procedimiento concursal.

Algunas corrientes doctrinarias afirman que no es prudente realizar ninguna clase de enumeraciones de actos que den lugar al concurso, debiendose admitir una facultad más amplia de investigación judicial acerca de la efectiva insolvencia del deudor.

\subsubsection{El sujeto pasivo}

Respecto del sujeto pasivo, unánimemente la doctrina se alinea en la dirección de aquellos que afirman que debe regularse una ley única de concursos, sea, aquél, civil o comerciante. Básicamente la legislación concursal mo- 
derna se dirige a las empresas, ya que es a través de éstas que se produce la insolvencia, ya sea del civil o del comerciante, distinción que el día de hoy no tiene mayor transcendencia.

\subsubsection{Publicidad y registros públicos}

Especial consideración se debe dar a la inscripción en los registros públicos de determinados actos, es decir, la publicidad debe ser un medio utilizado por la ley para denunciar ciertas operaciones y poner en conocimiento del interés público, a través del registro (publicidad registral) y medios de comunicación (periódicos), los estados patrimoniales que el tercero debe conocer.

\subsubsection{Medidas de conservación}

En cuanto a las medidas de conservación de la integridad patrimonial, debe mantenerse el concepto de desapoderamiento, y las medidas de conservación deberán agilizarse admitiendo, sin embargo, la continuación de la empresa, siempre que ello resulte económicamente posible y sea ventajoso para los intereses de las partes involucradas, lo que se deberá evaluar con criterio técnico.

\subsubsection{Los actos del concursado y retroactividad de la quiebra}

Para efectos del régimen de los actos del concursado anteriores a la declaración y a consideración de los posteriores, gran parte de la doctrina afirma que debe declararse expresamente que los actos del concursado posteriores a la declaración del concurso son ineficaces para imputar derechos patrimoniales a los acreedores anteriores, existiendo además ciertos actos que deben declararse ineficaces objetivamente frente a la masa, tal es el caso de las transferencias a título gratuito, la constitución de garantías sobre deudas que antes no las tenían, etc.

Nos encontramos aquí ante el tema de la retroactividad de la quiebra, retroactividad referida a todos aquellos actos realizados con anterioridad a la situación de insolvencia y que suelen perjudicar a la masa de acreedores concursales, y que se hallan en el «período sospechoso» que establecen di- 
versas legislaciones y que suele ser de seis meses anteriores a la declaración de insolvencia: quedarán nulos todos los actos de dominio y de administración realizados por el quebrado durante dicho período sospechoso. No se distingue aquí si los actos fueron a título gratuito u oneroso porque tal y como se ha mencionado anteriormente esto puede haber sido hecho con la intención de beneficiar al deudor directa o indirectamente, en perjuicio de la comunidad de acreedores. Además, en este estado de cosas es posible dar apariencia de onerosidad a los actos gratuitos. La realidad nos indica que el quebrado intuye, siente y percibe su situación de desarreglo económico; antes de que la quiebra sea declarada, suele transcurrir un período de tiempo durante el cual el deudor puede realizar actos de administración, de gravamen o disposición de sus bienes, con el objeto de beneficiarse él directamente, de favorecer a algunos acreedores, transferirlos a los familiares, amigos o personas de confianza para evitar su posterior ejecución concursal, o finalmente para retrasar la quiebra.

La estricta aplicación de los efectos de la quiebra sobre el contrato no ejecutado aún o en ejecución, va en contra de la natural equivalencia de las prestaciones, permitiendo que los representantes de la quiebra exijan de la otra parte el pago fiel e íntegro de su obligación, mientras que por otro lado algunas legislaciones determinan que la obligación que tiene el quebrado de cumplir, deberá someterse a la masa de la quiebra ${ }^{20}$.

En el caso de los contratos de tracto sucesivo, en aplicación de los principios de la quiebra tendría que exigírsele a la otra parte el reiterado cumplimiento de sus prestaciones, mientras que el quebrado estaría imposibilitado de hacerlo por encontrarse en quiebra. Sin embargo, entiende alguna parte de la doctrina, y concuerdo con ella en que deberá afirmarse con carácter general que la quiebra de una parte faculta a la otra para solicitar la resolución del contrato de tracto sucesivo, con el objeto de evitar algunos perjuicios y desequilibrios que se podrían presentar como consecuencia de la aplicación de los principios del derecho concursal ${ }^{21}$.

\footnotetext{
${ }^{20}$ Broseta Pont, Manuel. op. cit., p. 673.

${ }^{21}$ lbidem, p. 673.
} 


\subsubsection{Efectos de la declaración de insolvencia}

La declaración de insolvencia también manifiesta ciertos efectos patrimoniales; tal es el caso de la conversión dineraria de todas las deudas al momento de la declaración de insolvencia, el vencimiento anticipado de los créditos contra el deudor, la paralización de devengo de intereses por la deuda del quebrado, y la compensación de deudas y créditos del quebrado.

\section{La protección de la empresa como idea fundamen- tal del derecho concursal moderno}

Como hemos podido apreciar, la salud de la empresa pasó a ser una de las finalidades del derecho de quiebras, del derecho concursal, del derecho de las empresas en dificultades, como se le quiera denominar. Como ya se ha dicho, esto no implica que el deudor, los acreedores, la protección del crédito, la organización de un procedimiento colectivo, etc., dejen de tener importancia; simplemente se ha tomado conciencia de que existe una finalidad adicional que es necesario cautelar ${ }^{22}$.

Históricamente se ha interpretado que la eliminación del deudor significaba la eliminación de la empresa también, incluso en aquellos supuestos o realidades en las que era susceptible de sanear y darle una utilidad económica al conjunto empresarial. La eliminación del deudor no siempre implica la eliminación de la empresa y es justamente la supervivencia de la empresa lo que puede ayudar a eliminar deudores satisfechos, en vez de deudores insatisfechos cuyo crédito, aunque sea parcial, pasa a ser incobrable.

Debemos entender que solamente en la medida en que la empresa funcione, los acreedores cobrarán sus créditos, los trabajadores mantendrán su empleo, los accionistas conservarán su inversión, el Estado se beneficiará con el pago de impuestos, los proveedores tendrán aseguradas sus ventas, y los clientes podrán gozar de un producto en el mercado que les sea beneficioso. Es por ello que la preservación de la empresa como principio motor del nuevo derecho concursal, marca la diferencia con el antiguo derecho de quiebras.

\footnotetext{
${ }^{22}$ Paillusseau, Jean. op. cit., p. 660.
} 
Como dice Paillusseau, a las finalidades tradicionales del derecho de quiebras se les adiciona una nueva finalidad. La mayor parte de las veces las finalidades serán complementarias unas de otras. En algunos casos habrá un conflicto; en ese supuesto será necesario establecer una jerarquía entre las diversas finalidades ${ }^{23}$.

El concepto de interés social ha evolucionado no solamente en lo que se refiere al derecho concursal, sino que es destacable por ejemplo la evolución de este concepto en el ámbito del derecho societario y en otras áreas del derecho. En beneficio de ese interés social es que el día de hoy se reconoce que la prevención de las dificultades es un punto fundamental del nuevo derecho de las empresas en dificultades. Creando mecanismos de prevención adecuados, de alguna manera se está favoreciendo la continuación de las empresas al poder prever y subsanar con tiempo, corrigiendo una situación que podría volverse insalvable.

\subsection{La prevención de las dificultades de las empresas ${ }^{24}$}

Sobre la empresa como conjunto económico tienen influencia las tasas de interés, la regulación del crédito, el aparato impositivo fiscal, las cargas sociales, etc., aspectos que posibilitan que las reglas de juego sean distintas en un país y en otro, lo que enmarcado en el contexto de la competencia internacional da lugar a que unas empresas en algunos países tengan mayores problemas que otras.

También influye sobre la empresa la calidad de la gestión, la innovación, la capacidad de trabajo de sus dirigentes y de su personal. Sin embargo, no podemos desconocer que existen aspectos que no dependen directamente de la empresa mercantil, que tienen que someterse a ciertas disposiciones impuestas por el gobierno de turno, el Estado y el mercado internacional.

La prevención de las dificultades depende muchas veces de una mejora en la calidad de la información financiera, así como en la instauración de

\footnotetext{
${ }^{23}$ Ibídem, p. 660.

${ }^{24}$ Ver Ibídem, pp. 663-664.
} 
procedimientos de alerta y procedimientos de solución. El Estado y el gobierno de turno tendrán su parte dentro de los mecanismos de prevención promulgando normas que vayan contra la competencia desleal, los monopolios, creando los mecanismos legales necesarios para una adecuada prevención sobre la base de normas positivas y del «deterrance» normativo y jurisprudencial.

\subsection{Algunos aspectos preventivos a considerar}

\subsubsection{La defensa del interés social}

De un tiempo a esta parte en las diversas legislaciones se vienen acentuando los mecanismos de protección de los intereses sociales, distinguiéndose el interés social del interés de los accionistas, distinguiéndose el interés de la sociedad como tal del interés de los accionistas mayoritarios, y distinguiéndose en general el interés social del interés de los particulares.

La sociedad como ente jurídico autónomo e independiente de sus miembros, es capaz de tener también sus propios intereses, distintos muchas veces al de los propios accionistas. No solamente podemos afirmar que la persona jurídica es distinta de los miembros que la componen, lo que trae como consecuencia una separación de responsabilidades y una autonomía patrimonial, entre otras características, como consecuencia del otorgamiento de la personalidad jurídica; sino que esta separación de responsabilidades que conlleva a una separación patrimonial nos permite entender con mayor claridad la diferencia entre interés social e interés de los socios de la persona jurídica.

Muchas veces son las decisiones de las mayorías y de los accionistas las que llevan a la sociedad a un estado de falencia, y los accionistas se apoyan en la responsabilidad limitada, por lo menos en el caso de las sociedades anónimas, para sobre la base del concepto de mayorías tomar decisiones que atentan contra el interés social, en perjuicio de la persona jurídica y en perjuicio de la comunidad en su conjunto, que puede verse afectada cuando la empresa se encuentre en una situación de insolvencia a la cual concurren una diversidad de intereses.

La doctrina societaria moderna ha ido creando mecanismos de protec- 
ción del interés social a través de la delimitación clara y precisa del objeto social, que cumple la función de ser no sólo el límite a la capacidad de la sociedad, sino un parámetro para determinar la legitimidad de los actos de los representantes.

Algunos sistemas jurídicos han incorporado a través de la ley o de la jurisprudencia la teoría del levantamiento del velo societario o de la personalidad jurídica, sobre la cual se hará una breve referencia en las páginas siguientes y que responde a la necesidad de proteger a la sociedad en su conjunto respecto de actos fraudulentos que se pretenden cometer al amparo y cubiertos por el manto de la personalidad jurídica.

\subsubsection{La organización patrimonial y financiera ${ }^{25}$}

El derecho societario regula y norma algunas medidas de prevención dirigidas básicamente a dotar a la empresa de un contenido patrimonial efectivo y real; tal es el caso por ejemplo de:

1. La regulación de los aportes.

2. Verificación de una valorización real del aporte en especie.

3. Prohibición en el caso de las sociedades anónimas, de los aportes de industria (la no existencia de la figura del socio industrial).

4. En los casos de aporte dinerario, ya sea para la constitución de la sociedad o como consecuencia de un aumento de capital, es necesario el depósito en una institución bancaria, para lograr la integración del capital social.

5. La suscripción del total del capital y el pago cuando menos del $25 \%$ de cada acción.

6. Disposiciones que prohíben el reparto de utilidades antes de cubrir las pérdidas.

\footnotetext{
${ }^{25}$ Ver Ibidem, pp. 665-668.
} 
7. En algunas legislaciones se exige un monto mínimo de capital social para las sociedades anónimas.

8. Restricciones a la adquisición por la sociedad de sus propias acciones.

Todas estas medidas, la mayoría de las cuales podemos encontrar en la legislación peruana, evitan que los terceros contratantes con la sociedad y/o los acreedores se vean burlados respecto de la situación real de la empresa.

Si bien es cierto no hay una garantía absoluta respecto de la situación real de la empresa, estas medidas específicamente contempladas en la ley general de Sociedades pretenden garantizar en alguna medida el patrimonio de la sociedad, el cual constituye la garantía económica para los intereses en juego en el derecho concursal.

Contempla la ley adicionalmente algunas posibilidades financieras; por ejemplo, el que la empresa pueda emitir bonos para financiarse en lugar de tener que acudir al crédito bancario, que puede ser más oneroso. Esto también ayudará al crecimiento patrimonial de la empresa y es también una medida que contemplan diversas legislaciones.

Será necesario analizar qué medidas adicionales se pueden introducir con el objetivo de proteger el patrimonio de la empresa, que es la garantía de los terceros. Tal vez la primera de estas medidas sería exigir un capital mínimo para las sociedades anónimas, como ha sucedido en España con la publicación del real decreto legislativo 1564/1989 del 22 de diciembre de 1989, que aprueba la nueva ley de Sociedades Anónimas.

\subsubsection{La organización del poder}

Si bien es cierto poder y propiedad o tenencia de capital no es lo mismo, sí existe una relación estrecha entre el poder y la propiedad de las acciones. El ejercicio del poder societario depende principalmente de las mayorías, que son las que decidirán aquello que les será más beneficioso. No es necesario tener la propiedad total de las acciones para ejercitar o tener poder; será suficiente tener un número determinado de acciones para ejercitar el 
poder a través del concepto de mayoría. Para una debida organización del poder es necesario controlar el abuso de poder, y esto se logra, en primer término, cautelando el interés social de las empresas, así como el interés de la sociedad en su conjunto, de los terceros, y otorgando protección adecuada a los derechos de los accionistas minoritarios.

En algunas legislaciones se prohíbe que los dirigentes, aprovechando de sus poderes, puedan formalizar contratos con la sociedad reportándose ventajas personales en perjuicio de esta última. Esto que parece evidente, es algo que se hace con frecuencia.

El tema de la responsabilidad de los directores y gerentes y el tema de los derechos de los accionistas minoritarios, son temas de sumo interés en el derecho societario. Como no es materia del presente artículo analizar estos aspectos, no me voy a extender al respecto; sin embargo, no quiero dejar de mencionar que la protección y la cautela de estos derechos y de estos intereses es en alguna medida un mecanismo de prevención por el que se evita que como consecuencia de estos abusos se tomen decisiones que pueden ser mayoritarias y que son cómplices para que la empresa llegue a una situación de insolvencia que desemboque en las materias relacionadas con el derecho concursal y la reestructuración empresarial.

Es importante no solamente fiscalizar y tener cierto control en el caso de los contratos a firmarse por la sociedad por los dirigentes sociales, sino también respecto a los préstamos a accionistas, aspectos éstos que se prestan a abusos por parte de las mayorías.

Tenemos como antecedente una sentencia de la Corte de Casación en Francia que confirmó lo actuado por la Corte de París, que declara configurado el delito porque el presidente director general de una sociedad anónima había percibido remuneraciones autorizadas por el consejo directivo, que según la sentencia en cuestión «eran excesivas» visto que desde el año 1970 la sociedad había disminuido considerablemente su actividad, y que durante dicho período los montos de sus ventas no habían sido suficientes y que dichas remuneraciones sólo pudieron ser pagadas con préstamos fuertemente onerosos que el presidente concertó para dicho fin $^{26}$.

${ }^{26}$ Ibidem, p. 668. 
Situaciones como éstas son frecuentes y la jurisprudencia en algunos países no ha dudado en declararlas y condenarlas. El sustento y el soporte de dichas sentencias y su sanción está dado en la intención de proteger a la empresa y los intereses que ella representa ${ }^{27}$.

Podemos encontrar jurisprudencia que viene afirmando desde hace algún tiempo que aun cuando el consentimiento sea unánime de todos los socios, no desaparece el carácter delictivo del abuso de los bienes o del crédito de la sociedad, o el abuso del poder, ya que lo que se protege no es el interés de los asociados o socios, sino el patrimonio social y el interés de la sociedad como tal. Reiteramos pues la necesidad de distinguir el interés social del interés de la mayoría, así como también la de fijar criterios de responsabilidad claros para los directivos y responsables de las empresas, sobre todo cuando actúan en beneficio propio directo o indirecto.

\subsubsection{La información financiera y jurídica}

Es evidente que la rapidez y la calidad de la información influyen en la situación de las empresas. La información no sólo es importante para los dirigentes de la empresa y para los accionistas, sino también para todos aquellos que de alguna forma están vinculados a ella (trabajadores, acreedores, etc.). Los grandes juristas dedicados al derecho societario reconocen en la actualidad la importancia de la publicidad de la información. Debe darse la mayor publicidad posible a la información que es de interés social y público. Algunos argumentarán que por más publicidad que exista igual seguirán sucediendo los problemas de insolvencia empresarial, y probablemente tengan razón, pero en la misma forma podemos argumentar y reconocer que, por ejemplo, nadie puede negar que el derecho de información del accionista es un derecho político sumamente importante. Es importante, sin embargo, anotar que muchas veces este derecho de información no es ejercido adecuadamente por los accionistas que en algunos casos ni siquiera asisten regularmente a las juntas de accionistas o de socios. Por el hecho de que sea desatendido o no utilizado por muchos o pocos accionistas, no significa que se va a eliminar el derecho de información de los accionistas como un derecho político esencial de aquéllos, que permite la fiscalización y ayuda a

${ }^{27}$ Ibídem, p. 668-669. 
que el accionista esté preparado para decidir mediante el voto los destinos sociales.

Hay que distinguir entre el otorgamiento del derecho y el ejercicio del derecho. Es necesario otorgar la posibilidad para que por medio de la publicidad los intereses involucrados estén al día respecto de la situación de la empresa sobre la cual tengan algún interés.

El primer grado de información de una empresa es el relativo a la situación de su patrimonio y de la marcha de su explotación, y para esto es necesario conocer acerca de la naturaleza de sus bienes, los gravámenes, su pasivo, su deuda, sus intereses, los compromisos contraídos, fianzas, avales, garantías, etc. Sin embargo, estos datos no son suficientes; será necesario conocer acerca de la explotación de la empresa, pues los montos en cuanto a volumen por unidades monetarias son relativos, de acuerdo con la proyección y el volumen de operaciones del negocio.

Es importante no solamente el estado actual del negocio, su patrimonio y su pasado, sino el futuro, qué posibilidades realmente existen de lograr el equilibrio financiero y cuál es la previsible evolución de la marcha de la empresa. La cuarta directiva de la Comunidad Económica Europea dispuso que los informes de gestión deberían contener información sobre los acontecimientos de importancia ocurridos incluso después del cierre del ejercicio y que hayan incidido sobre la evolución de la marcha de la socie$\mathrm{dad}^{28}$.

\subsubsection{El levantamiento del velo de la personalidad}

No podemos terminar el análisis acerca de la prevención de las dificultades sin mencionar la importancia de tener acceso a la información relativa a la composición y estructura del grupo al cual pertenece la empresa. Es cierto que los acreedores y terceros no tienen un derecho directo contra la sociedad dominante y por lo tanto la información no da posibilidad de acción alguna. Sin embargo, de todas formas es un dato importante a considerar, y la evolución del derecho se dirige en algunas legislaciones a lo que se conoce

${ }^{28}$ Ibidem, p. 675. 
en la doctrina y jurisprudencia anglo y norteamericana como el levantamiento del velo societario. Es más, algunas legislaciones están imponiendo que se presenten estados contables consolidados. La Comunidad Económica Europea $^{29}$ elaboró un proyecto de séptima directiva, imponiendo a toda sociedad matriz que tenga su sede en algunos de los países de la comunidad la obligación de presentar sus estados contables consolidados.

Es claro que los accionistas de una sociedad anónima, tipo societario más utilizado, sólo responden frente a la sociedad y terceros hasta por el monto de sus aportes (principio de responsabilidad limitada). Esta separación de responsabilidades se ha venido cuestionando en la doctrina y jurisprudencia mediante la doctrina del levantamiento del velo societario (disregard of corporate entity) ${ }^{30}$. Si bien es cierto que toda persona jurídica constituye un ente distinto a las personas que la conforman, ya sean éstas naturales o jurídicas, y se establece una separación de patrimonios mediante la limitación de responsabilidades, esta teoría del «disregard of corporate or legal entity» pretende evitar los abusos y fraudes que se hacen al amparo del manto protector de la persona jurídica.

Esta teoría consiste en tratar a la sociedad como si ésta no existiera, prescindiendo de la forma externa de la persona jurídica, penetrando en la interioridad de ésta y examinando así los intereses reales que ahí se encuentran. Implica esta teoría prescindir de la personalidad societaria, despersonalizarla para que se frustre el resultado antijurídico que con su constitución se pretendió efectuar ${ }^{31}$.

Como lo afirma Eduardo Zannoni, haciendo referencia a Héctor Masnatta, si se abusa de la persona jurídica «para alcanzar fines contrarios a la vida de la sociedad, es posible adoptar medidas contra los individuos respecto de las verdaderas relaciones encubiertas tras la máscara de la persona jurídica, que no puede ser obstáculo para el cumplimiento de una sentencia

${ }^{29}$ Ibidem. p. 674 .

${ }^{30}$ Black Law Dictionary, 6ª edición, West Publishing Co., 1990.

31 ZANNONI, Eduardo, «La normativa societaria ante los actos fraudulentos de la sociedad. Replanteo de la Teoría del Disregard», Revista de Derecho Comercial, año 1978, Ediciones Depalma, p. 1607. 
justa. No pueden legalizarse en mérito a preceptos de lógica, ni al dogma de la diversidad entre la persona jurídica y sus miembros, actos abusivos de ninguna naturaleza» ${ }^{32}$.

La teoría del levantamiento del velo societario permite que los tribunales puedan prescindir de la forma jurídica para conocer realmente las responsabilidades personales sobre los accionistas, ejecutivos y directores de la empresa. Esta doctrina norteamericana reconoce la aplicación de esta teoría básicamente para los casos en que se presuma la existencia del fraude, y específicamente a personas o entidades que se hallen en real conexión con el quebrado. Lo que se pretende es identificar la realidad y poner en evidencia la identidad real entre personas jurídicas y personas físicas o jurídicas accionistas de ella. La teoría se sustenta en el hecho de que no se puede considerar que la situación de la empresa subordinada o controlada es ajena a la sociedad dominante, debido a que siendo esta última titular de la totalidad (o la casi totalidad) de las acciones de la subordinada, que es a su vez la deudora, los negocios de la subordinada no le son extraños a la dominante, que es la que en realidad administra y dirige los asuntos de la subordinada/deudora. Se mencionó anteriormente cómo en España, con motivo del decreto ley español del 20 de octubre de 1969 , referido a administración de empresas embargadas, se hacía extensivo el embargo y la administración a los grupos de empresas cuando existía «control legal» tal y como lo definiera la ley en España ${ }^{33}$. La incorporación de esta doctrina e ideas a través de la legislación o jurisprudencia en el Perú, traería importantes consecuencias para el derecho concursal y societario.

La teoría del levantamiento del velo pretende evitar que a través de la apariencia formal societaria se pueda esconder la realidad de un único interés, evitándose que al amparo de una forma jurídica determinada se pueda actuar fraudulentamente, burlando a la buena fe y a la sociedad en su conjunto.

32 Ibidem, p. 1607.

. ${ }^{33}$ Vicent ChuliÁ, Francisco, op. cit., p. 766. 


\section{La legislación peruana: la ley de Reestructuración Empresarial, decreto ley $N^{\circ} 26116$ y su reglamen- to $^{34}$}

La ley de Reestructuración Empresarial, publicada con fecha 30 de diciembre de 1992 en el diario oficial El Peruano mediante decreto ley 26116, así como su reglamento, decreto supremo 044-93-EF, publicado en el diario oficial El Peruano de fecha 23 de marzo de 1993, establecen que estas normas se aplicarán para la reestructuración económica y financiera, para la liquidación extrajudicial y quiebra de empresas. Se excluye del ámbito de aplicación del decreto ley a las entidades sujetas a la supervisión de la Superintendencia de Banca y Seguros y a las Administradoras de Fondos de Pensiones (AFP), que se regirán por sus leyes respectivas. El decreto ley 26116 sustituye a la ley procesal de Quiebras, ley $\mathrm{N}^{\circ} 7566$.

Este decreto ley es parte del conjunto de normas que viene expidiendo el gobierno con el propósito de regular la actividad privada con un beneficio para la sociedad en su conjunto y para el consumidor en general. Es así como se han promulgado normas referentes a la protección al consumidor, la propiedad industrial e intelectual, la ley Antimonopolio, y se ha regulado la competencia desleal. La ley de Reestructuración Empresarial se da en un contexto de apertura del derecho mercantil hacia las nuevas tendencias; lo más interesante de esta ley está dado por la concesión a los acreedores de la decisión sobre el futuro de la empresa insolvente, planteando y cuestionando que el principal problema no está precisamente en sancionar al quebrado, sino en satisfacer a los acreedores que han quedado impagos. Mediante esta fórmula se les da la opción a los acreedores para que evalúen la posibilidad de reactivar la empresa, lo que finalmente pretende dar un mayor valor a la empresa reactivada que a la empresa quebrada, evitando de esta forma que una mayor cantidad de acreedores se queden impagos respecto de sus deudas.

Podrá argumentarse que en la legislación anterior la junta de acreedores también tenía la posibilidad de acortar la reactivación, pero el día de hoy

${ }^{34}$ Ley de Reestructuración Empresarial, decreto Ley 26116, Diario Oficial El Peruano del 30 de diciembre de 1992; y su reglamento, decreto supremo 044-93-EF, Diario Oficial El Peruano del 23 de marzo de 1993. 
la ley sugiere expresamente en el art. 5.1. la continuación de la actividad empresarial.

Características importantes de esta ley, son las siguientes:

1. Como ya se ha mencionado, la decisión de quiebra corresponde a los acreedores, que tienen además otras alternativas como la supervivencia de la empresa.

2. La gestión es controlada por los mismos acreedores a través de la junta de acreedores.

3. La administración, y en su caso, la liquidación de la empresa deudora, corresponde a un banco.

4. El banco liquidador reemplaza la figura del síndico de quiebra.

\subsection{El presupuesto de insolvencia. El presupuesto objetivo}

Algunas legislaciones justifican la apertura de un procedimiento concursal sustentado en presupuestos objetivos tales como cesación de pagos, embargo infructuoso, fuga del comerciante, etc., criterios que tal vez ayudan a distinguir la insolvencia de la cesación de pagos pero que no necesariamente implican la insolvencia definitiva.

La ley peruana establece un criterio objetivo al determinar que la declaratoria de insolvencia podrá ser solicitada por uno o varios acreedores impagos cuyos créditos superen en total el equivalente a 50 UITs* vigentes a la fecha de la solicitud, o por el mismo deudor siempre que acredite tener pérdidas que reduzcan su patrimonio a una cantidad inferior a la tercera parte. Se deberá solicitar esta declaratoria ante la Comisión de Simplificación del Acceso y Salida del Mercado.

Entiende la ley que el acreedor impago es aquél cuyo crédito exigible

* UIT = Unidad Impositiva Tributaria. 
se encuentra vencido y no ha sido pagado dentro de los treinta días naturales siguientes a su vencimiento. Tratándose de créditos que se vencen por armadas o cuotas sólo se computarán las armadas o cuotas vencidas por cualquier causa. También el artículo 2 establece que el deudor mismo podrá solicitar su declaratoria de insolvencia siempre que acredite tener pérdidas que reduzcan su patrimonio a una cantidad inferior a la tercera parte; es decir, estamos aquí ante la figura de la quiebra voluntaria.

La recomendación que se podría hacer respecto de este presupuesto objetivo, es que de acuerdo con el volumen de operaciones, el tamaño de la empresa y de su patrimonio, 50 UITs puede ser poco o mucho y que tal vez será necesario establecer una escala más justa, basada en una relación entre patrimonio o activos y pasivos. No se puede evaluar con el mismo patrón de medida las deudas de empresas que difieren grandemente en su patrimonio y volumen de operaciones.

\subsection{El procedimiento concursal}

Éste se inicia con la presentación de la solicitud de declaratoria de insolvencia, ya sea por parte del deudor, o por los acreedores de acuerdo con lo expuesto en el punto anterior.

La solicitud presentada por los acreedores deberá estar acompañada con copia de la documentación sustentatoria de los respectivos créditos. Si el que solicita la declaratoria de insolvencia es el mismo deudor, se deberá acompañar copia del balance general y del estado de ganancias y pérdidas, estados de cambio en el patrimonio neto durante los tres últimos años, así como otra documentación que exige el reglamento en el decreto supremo $\mathrm{N}^{\circ}$ 044-93-EF en su artículo 2.

La Comisión de Simplificación del Acceso y Salida del Mercado, que es una de las comisiones del Instituto Nacional de Defensa de la Competencia y de la Protección de la Propiedad Industrial e Intelectual -INDECOPI-, creado con el objeto de proteger la competencia y los derechos de los consumidores y simplificar el acceso y salida del mercado de los agentes económicos, cita al deudor para que acredite, ya sea su capacidad de pago o su insolvencia. En caso de que el deudor, ya sea mediante la cancelación u ofreciendo cancelar a satisfacción de los acreedores cuyos 
créditos dieran origen a la solicitud, $\mathbf{u}$ otorgando $\mathbf{u}$ ofreciendo otorgar a satisfacción de los acreedores garantía real o personal en beneficio y con aceptación de los acreedores que solicitaran la declaratoria de insolvencia, acredite su capacidad de pago, se expedirá una resolución denegatoria de la solicitud de declaratoria de insolvencia.

En caso de que la Comisión compruebe que el deudor no tiene capacidad de pago, se le declarará insolvente, citándose en la misma resolución a todos los acreedores para que se reúnan en junta, la misma que se realizará en el lugar, día y hora indicados en la convocatoria, señalando además lugar, día y hora para la segunda y tercera convocatorias, las mismas que deberán hacerse por intermedio de El Peruano y en otro diario de circulación en la respectiva localidad. Las publicaciones deberán hacerse por dos días consecutivos, debiendo mediar entre la publicación del último aviso y la realización de la junta por lo menos veinte días útiles, debiendo la junta reunirse a los veinte días siguientes a la fecha de publicación del último aviso. Entre la primera y segunda convocatoria, así como entre la segunda y tercera, deberán mediar cuando menos dos días útiles.

\subsubsection{Verificación y reconocimiento de créditos}

Los acreedores, para participar en la junta convocada, deberán presentar ante la Comisión hasta el décimo día hábil anterior a la fecha señalada para la realización de la junta, los títulos que acrediten la existencia de sus créditos, se encuentren éstos vencidos o no, para que la Comisión reconozca la titularidad, legitimidad y cuantía de los mismos.

La Comisión, considerando el elevado número de acreedores presentados y la complejidad del reconocimiento de los créditos, podrá postergar la realización de la junta señalando nueva fecha, la misma que deberá realizarse en un plazo no mayor de veinte días útiles contados a partir de la fecha de publicación.

La Comisión deberá realizar el análisis de los créditos presentados a reconocimiento investigando su cuantía y legitimidad, luego de lo cual expedirá una resolución, la misma que deberá ser notificada a los acreedores, en la que constará la relación de los créditos cuya titularidad, legitimidad y 
cuantía reconocen. El acreedor que no obtenga reconocimiento puede apelar ante el tribunal.

El artículo 11 del reglamento permite que los acreedores cuyos créditos no hayan sido oportunamente presentados o reconocidos por la Comisión, puedan solicitar en cualquier momento su reconocimiento con el objeto de participar en las sesiones de la junta. El reconocimiento tardío no invalida los acuerdos adoptados por la junta con anterioridad, pero podrán ser impugnados si no hubiese vencido el plazo para hacerlo.

\subsubsection{La junta de acreedores}

La junta de acreedores elegirá de su seno al presidente y vicepresidente, así como podrá elegir de entre sus miembros a un comité al cual se le podrá delegar las atribuciones que le confiere el decreto ley 26116 , excepto aquellas atribuciones que corresponden a la junta en su conjunto y que no pueden delegarse a los comités; tal es el caso de la decisión respecto del destino de la empresa. La empresa deudora podrá asistir a las sesiones debidamente representada para expresar sus puntos de vista.

Todo acuerdo de la junta debe constar en actas, las que deberán suscribir el presidente, el representante de la Comisión y un acreedor designado para tal efecto.

\subsubsection{Atribuciones de la junta}

La nueva legislación otorga a la junta tres alternativas respecto del destino de la empresa:

1. Continuar con la actividad de la empresa, entrando en un proceso de reestructuración económica y financiera.

2. Disolver y liquidar la empresa, procediéndose a la liquidación extrajudicial.

3. Declarar judicialmente la quiebra. 
Las opciones que la misma ley propone, evitan que la quiebra se declare desde el primer momento. Podemos entonces afirmar que existen fases previas a la quiebra; la primera será la evaluación de INDECOPI respecto de la situación economica y financiera para determinar si el deudor es o no insolvente; luego de esta fase será la junta de acreedores, una vez verificados los créditos, quien definirá qué acción tomar. Es en la opción de la reestructuración de la empresa donde realmente encontramos el aporte más importante de la nueva legislación. Bajo esta opción el deudor puede llegar a tener poco o ningún control, con lo que se evita que la empresa deudora al mantener el control utilice éste para forzar a los acreedores, presionados y necesitados de formalizar un convenio, que, aunque perjudicial, es menos malo que una quiebra manejada por un síndico de quiebras.

Para que la junta quede debidamente convocada se requerirá en primera convocatoria acreedores que representen cuando menos el $70 \%$ de los créditos reconocidos; para la segunda y tercera convocatoria se requerirá $51 \%$ de los créditos reconocidos.

Para efectos de tomar una de estas tres decisiones que la ley plantea, los acuerdos deberán adoptarse con el voto de los acreedores que representen créditos por un importe superior al $70 \%$ del monto total. Deberá estar presente un representante de la Comisión, quien certificará la existencia del acuerdo. Para cualquier acuerdo sobre otros puntos será suficiente el voto conforme de los acreedores que representen créditos por un importe superior al $50 \%$.

Si luego de tres convocatorias la junta no se instalara, la Comision podrá solicitar la declaración judicial de quiebra; igual se procederá si instalada la junta ésta no tomase acuerdo sobre el destino de la empresa dentro de los treinta días útiles siguientes.

Tendrán derecho de impugnación la empresa o los acreedores que representen créditos de cuando menos $20 \%$ del total de los créditos reconocidos, pudiendo impugnar los acuerdos adoptados en junta de acreedores dentro de los diez días siguientes hábiles a la fecha en que se puso en conocimiento el acuerdo. La Comisión deberá resolver dentro de un plazo que no exceda de diez días útiles a partir de la fecha de su recepción. A solicitud de los acreedores que presentaron la impugnación se podrá ordenar la suspensión del acuerdo impugnado en cuanto estuviese en ejecución. Las 
impugnaciones contra un mismo acuerdo deberán resolverse en una sola resolución, acumulándose de oficio a la impugnación que se presentó en primer lugar. El plazo para resolver se contará a partir de la última impugnación.

Las resoluciones de la Comisión podrán ser impugnadas ante el tribunal, el que resolverá en un plazo que no excederá de quince días útiles contados a partir de la fecha de la recepción de la impugnación. La resolución del tribunal pondrá fin a la vía administrativa.

El registrador público inscribirá en el registro los acuerdos adoptados en junta, el convenio de liquidación extrajudicial y el auto judicial que declara la quiebra, teniendo efecto frente a terceros desde que son adoptados, suscritos o quedan consentidos, respectivamente.

\subsection{El orden de preferencia}

Al igual que en casi todas las legislaciones que hemos podido revisar, la legislación peruana también establece un orden de preferencia o prelación respecto al pago de los créditos, siendo el orden el siguiente: dores.

1. Pago de remuneraciones y beneficios sociales adeudados a trabaja-

2. Créditos alimentarios.

3. Créditos de origen tributario.

4. Créditos garantizados con hipoteca, prenda o anticresis, respecto a los bienes afectos a la garantía.

5. Otros créditos según su actividad, y en caso de tener la misma actividad y constar en algún registro, según el orden en que han sido inscritos en el mismo. De no poderse establecer este orden, se pagarán a prorrata.

La preferencia de los créditos implica que en el eventual caso de que los activos, los valores y los bienes de la sociedad no puedan satisfacer al total de acreedores, quedarán impagos aquellos que se encuentren al final en 
el orden de preferencia, ya que el pago a los acreedores se hará hasta donde alcancen los bienes de la empresa. Tratándose de los créditos adeudados a trabajadores por remuneraciones, créditos tributarios o alimentarios, éstos serán pagados en forma proporcional a los montos adeudados (art. $30 \mathrm{del}$ reglamento).

A efectos de simplificar la representación de los créditos en la junta de acreedores, se ha establecido que todo crédito derivado del pago de remuneraciones y beneficios sociales, así como aquellos que tengan como origen la falta de pago de tributos, serán considerados en cada caso como uno solo, siendo los acreedores representados por un trabajador que designe el Ministerio de Trabajo y Promoción Social para el caso de los «créditos laborales», y por el Ministerio de Economía y Finanzas para el caso de tributos.

Es necesario indicar que, respecto a la prelación del crédito, la novedad la constituye el privilegiar el crédito tributario, el que en la anterior legislación era tratado como un crédito común, colocándosele actualmente en un rango anterior incluso al crédito con garantías reales. No es menos cierto que el Código Tributario lo ha colocado también delante de los créditos con garantía, pero esto sólo se producía en los casos en que la deuda tributaria hubiese sido notificada con anterioridad.

\subsection{La reestructuración de empresas}

La ley de Reestructuración Empresarial dispone que la junta de acreedores debidamente convocada podrá optar por una de estas alternativas: disolución y liquidación de la empresa, declaración judicial de quiebra y continuación de la actividad de la empresa vía un proceso de reestructuración. Considerando que es esta última la novedad más interesante que contempla la nueva legislación relativa al derecho concursal, es que expondremos sus características.

Ésta es, siguiendo la corriente moderna, la gran novedad conceptual, a nivel de la filosofía de derecho concursal, respecto de la legislación anterior de quiebras; es una modificación que afecta la esencia misma de la ley. La reestructuración de empresas se plantea como una alternativa expresa que 
contempla la ley y que se presenta para los acreedores en el entendido de que es posible que la empresa en funcionamiento tenga mayor valor que los bienes que aisladamente posea. Existe siempre un intangible (good will, know how) de difícil valorización, y mediante la reestructuración empresarial se estaría rescatando.

A efectos de que se pueda reestructurar la empresa, la junta de acreedores deberá optar por esta opción y decidir la continuación de las actividades, teniendo como sustento la existencia de posibilidades reales para su reposición económica y financiera, para lo cual se deberá realizar evaluaciones y análisis respecto del monto del capital aproximado que requiere, la factibilidad de capitalizar acreencias y su posterior venta.

El reglamento en el artículo 15, inciso d establece que en caso de capitalización de deudas a favor de bancos e instituciones financieras, las acciones, participaciones o cualquier otro título representativo del aumento de capital, deberán venderse en bolsa o a través de acciones de bolsa al final del período de reestructuración.

El proceso de reestructuración no podrá ser mayor a un año a partir de la fecha del acuerdo de la junta, pudiendo ser prorrogado por acuerdo de la misma cuantas veces lo estime necesario la junta de acreedores. Para la prórroga se deberá cumplir con las mismas formalidades establecidas para la aprobación inicial.

La opción de la reestructuración empresarial implica que debe existir un régimen de administración, y en este proceso los acreedores pueden optar ya sea por continuar con el mismo régimen de administración u otorgar la administración a una institución financiera y de seguros, banco o entidad pública o privada, que a juicio de la Comisión (INDECOPI) conste con capacidad técnica para tal efecto, sea éste acreedor o no de la empresa en proceso de reestructuración. El administrador designado sustituirá, tal y como dice la ley, de pleno derecho en sus facultades, sin reservas ni limitación alguna, a los directores, representantes legales y apoderados de la empresa, teniendo facultad para celebrar toda clase de actos y contratos que fueran necesarios para lograr la recuperación económica y financiera. Cualquiera que sea la opción elegida por la junta, se suspende la competencia de la junta general de accionistas o asociados, o el titular de la empresa, cuyas funciones serán asumidas por la junta de acreedores. 
El acuerdo de junta de acreedores nombrando al administrador, deberá inscribirse en registros públicos dentro de los tres días hábiles siguientes desde su adopción, debiendo publicarse dentro de los tres días útiles siguientes al acuerdo de la junta. Estos avisos deberán informar sobre el régimen de administración, el administrador, etc. El administrador deberá proponer a la junta de acreedores, dentro de los sesenta días naturales siguientes a su designación, el plan de reestructuración al que se someterá la empresa durante el plazo de duración del proceso. En este plan deberá detallarse las acciones que se van a ejecutar y el cronograma del pago de los créditos hasta su cancelación, el financiamiento de la inversión requerida para continuar con la actividad empresarial, la política laboral, así como el presupuesto que incluya los gastos y honorarios del administrador. La junta deberá aprobar el plan de acuerdo con lo dispuesto en el decreto ley referido. Puede la junta concederle al administrador un plazo mayor a los sesenta días para la presentación del plan de reestructuración.

En caso de no ser aprobado el plan de reestructuración presentado, con el voto de los acreedores que representen créditos por un importe superior al 50\% del monto total, la junta podrá conceder quince días para que se adecúe el plan al acuerdo mayoritario, vencido el cual, sin que haya acuerdo, la junta deberá decidir por la liquidación extrajudicial o por la quiebra o remover al administrador del cargo por una sola vez, estando obligado el nuevo administrador a presentar el plan de acuerdo con los plazos previstos en la ley.

El acuerdo adoptado por la junta respecto de la continuación de la actividad empresarial, deberá presentarse ante el juez especializado en lo civil de turno, el mismo que deberá notificar al juez del tribunal arbitral o ejecutor coactivo que conozca de los procesos judiciales arbitrales o coactivos seguidos contra la empresa, para que se ordene el levantamiento de los embargos y de las demás medidas cautelares trabadas sobre los bienes de la misma. Asimismo, se suspenderán todos los procesos judiciales arbitrales o coactivos pendientes que se siguen contra la mencionada empresa y que tengan como objeto la ejecución de garantías reales, embargos definitivos o cualquier otra medida ordenada sobre los bienes de la misma.

A partir de la fecha de inicio del proceso de reestructuración se suspenderá la exigibilidad del pago de las obligaciones que tuvieran pendientes las empresas comprendidas en el indicado proceso con sus acreedores, que- 
dando sujetas al plan de reestructuración. El importe de las obligaciones podrá convertirse a dólares, al tipo de cambio venta promedio ponderado de la cotización de oferta y demanda publicado por la Superintendencia de Banca y Seguros del día en que se inicia el proceso de reestructuración. Se aplicará a estas obligaciones pendientes de pago la tasa de interés pasiva en moneda nacional o extranjera que estuviera pactada, en defecto de un régimen de intereses pactados, y si se ha hecho la conversión a dólares se aplicará la tasa de interés que publica la Superintendencia.

En cualquier momento durante el proceso de reestructuración, el representante legal de la empresa, el administrador o los accionistas que representen créditos por un importe superior al $50 \%$ del monto total y que consideren que no es posible la reestructuración, podrán solicitar al presidente de la junta que convoque a junta de acreedores para que se pronuncie sobre las otras alternativas previstas en el decreto ley, para cuyo acuerdo se requiere un importe superior al $70 \%$ del monto total de los créditos. Vencido el plazo del proceso de reestructuración de empresas, caducan las funciones de la junta de acreedores y del administrador, y asumirán su administración aquellos a quienes corresponda según los estatutos y quedará sin efecto lo dispuesto en el decreto ley respecto de la suspensión de los procesos y el levantamiento de los embargos y medidas cautelares trabadas sobre los bienes de la empresa.

El artículo 26 del reglamento estipula que ante el primer incumplimiento en el pago de las obligaciones de la empresa, el acreedor podrá solicitar ante el juez especializado en lo civil que deje sin efecto el levantamiento o suspensión, según sea el caso.

La ley sanciona con nulidad los actos y contratos realizados o celebrados por la empresa entre la fecha en que se citó a la primera junta y la fecha de notificación del auto judicial (art. 22 del reglamento).

Además de la alternativa de reactivar la empresa, la junta de acreedores puede optar por proceder a celebrar un convenio de liquidación extrajudicial sobre los bienes de la empresa deudora, o proceder a la alternativa más drástica que tiene la junta de acreedores, es decir, la quiebra y la disolución de la empresa, en cuyo caso el presidente de la junta solicitará al juez especializado en lo civil la declaratoria de quiebra correspondiente, adjuntando copia de los acuerdos adoptados en junta de acreedores. 
Adicionalmente, el reglamento establece que otras personas como el fiscal provincial, el liquidador y la Comisión en circunstancias específicas, podrán también solicitar la quiebra (art. 35 del decreto supremo 044-93-EF).

No nos extenderemos en el análisis de estas opciones, ya que son las alternativas típicas que se pueden encontrar en toda legislación sobre quiebras.

\subsection{Efectos de la declaratoria de quiebra}

Los efectos inmediatos del auto de declaratoria de quiebra son los siguientes:

1. Se produce un estado indivisible entre la fallida y sus acreedores, que comprende todos los bienes y obligaciones de ésta, aun cuando dichas obligaciones no hayan vencido en su plazo.

2. Los directores, gerentes y otros administradores de la fallida quedan privados del derecho de administrar los bienes de ésta, salvo los que sean inembargables conforme a ley. Es desapoderamiento no transfiere la propiedad de los bienes de la fallida a sus acreedores, sino sólo las facultades de hacerse pago de sus créditos con el producto de su realización. La administración de los bienes futuros que adquiere la fallida a título oneroso o gratuito con posterioridad a la declaratoria de quiebra, corresponderá al banco $o$ entidad liquidadora.

3. La administración corresponde al banco ratificado por el juez para tal efecto, quien administrará los bienes objeto del desapoderamiento, así como los bienes sobre los cuales la fallida tenga derecho de usufructo, cuidando de que los frutos liquidados, en ambos casos, ingresen a la masa de la quiebra.

4. Todas las obligaciones de pago de la fallida se harán exigibles aunque no se encuentre vencidas, descontándose aquellos intereses correspondientes del plazo que falte para el vencimiento, esto en los casos de obligaciones no vencidas. No podrá realizarse ninguna compensación que no se haya hecho antes conforme a ley. 
5. Todos los juicios pendientes contra la fallida ante otros jueces de cualquier otra jurisdicción y que puedan afectar sus bienes, se acumularán al proceso de quiebra, así como los nuevos juicios que se inicien contra la masa de la quiebra se sustanciarán ante el juez que conoce la misma. Igual sucederá con los procesos arbitrales que afecten los derechos y obligaciones de la fallida.

6. Los embargos y las demás medidas, y toda otra medida cautelar que se hubiese adoptado en los juicios acumulados, quedarán sin efecto a partir de la declaratoria de quiebra.

7. Los acreedores hipotecarios, prendarios o anticresistas harán efectivos sus derechos ante el juez de la quiebra con los bienes que estén especialmente afectos al pago de sus créditos.

8. Quedarán en suspenso, sólo con relación a la masa de la quiebra, los intereses de los créditos comunes que estuvieran vencidos a la fecha de la declaratoria de quiebra, y una vez pagado el valor de estos créditos entrarán a participar proporcionalmente en el remanente por los intereses que se devenguen con posterioridad a la fecha de su vencimiento.

\section{5.1 Efectos retroactivos de la quiebra. Artículo 21}

La declaratoria de quiebra de la empresa produce retroactivamente la nulidad de los gravámenes, transferencias y demás actos y contratos, ya sean a título gratuito u oneroso, que afecten su patrimonio, por actos celebrados por la fallida dentro de los seis meses calendarios anteriores a la fecha del acuerdo de la junta de acreedores. El tercero de buena fe, adquiriente a título oneroso de algún derecho de la fallida, no resultará afectado con la nulidad una vez inscrito su derecho, salvo que se pruebe que actuó de mala fe. La acción de nulidad prescribe en el plazo de dos años contados a partir de la fecha del acto o contrato correspondiente.

\subsection{Liquidación de la quiebra}

Este proceso no podrá exceder de dos años contados a partir de la fecha del auto que declara la quiebra, salvo que la junta prorrogue dicho plazo a su 
vencimiento. La entidad liquidadora, una vez asumido el cargo, deberá adoptar las medidas necesarias liquidando los negocios de la fallida y, entre otras, pagar los créditos correspondientes. Una vez que se haya pagado todos los créditos o agotado el activo, el juez de la quiebra expedirá una resolución que declarará el sobreseimiento definitivo del proceso, con lo que se produce la extinción de la empresa.

Los sobrantes de la liquidación, si los hubiera, se deberán entregar a los accionistas o socios de la fallida. Por otro lado, los acreedores que no sean pagados por insuficiencia de la masa, así como aquellos créditos que hayan sido rechazados o presentados para su reconocimiento de manera extemporánea, conservarán acción contra la fallida, con el objeto de perseguir los bienes que ésta adquiera después de terminada la quiebra.

\section{Comentarios finales}

El tema del derecho concursal ha sido pocas veces tratado por la doctrina en el Perú; sin embargo, creemos que es un tema de total actualidad y que a través de la legislación recientemente promulgada en diciembre de 1992, se están incorporando tendencias jurídicas de actualidad. En el mundo de hoy se analizan con mayor interés temas cuya existencia no es reciente, pero que no han sido realmente profundizados en el Perú, muchos de ellos relacionados con los derechos económicos de la empresa y el derecho empresarial, como son los temas acerca de la competencia desleal, las leyes antimonopolio y la protección del consumidor, entre otros.

\subsection{Comentarios a la ley peruana}

Respecto de los antecedentes legislativos inmediatos en el Perú relacionados con el derecho concursal, es necesario anotar que el artículo primero de la ley procesal de Quiebras, ley número 7566 , establecía que el juicio de quiebra «tiene por objeto realizar en un solo procedimiento los bienes de una persona natural o jurídica, sea o no comerciante, a fin de proveer el pago de sus deudas en los casos y las formas determinados por la ley» ${ }^{35}$. Del análisis

${ }^{35}$ Flores Polo, Pedro, Derecho de Quiebras, Marsol Perú Editores, 1989. p. 121. 
de este artículo podemos apreciar que el objetivo principal de la ley procesal de Quiebras era la realización de los bienes del deudor en un procedimiento único y con el objeto de pagar a los acreedores.

No había conciencia efectiva en el derecho positivo peruano de que la liquidación del patrimonio del deudor afectaba también otros intereses. Esta liquidación, y por lo tanto, la terminación de una actividad productiva, trae como consecuencia inmediata la pérdida de empleos y el perjuicio de aquellos acreedores cuyos créditos no estaban debidamente garantizados y cubiertos. No sería aventurado afirmar que el perjuicio como consecuencia de la finalización de la actividad productiva era mayor que los beneficios que podían percibir algunos acreedores, ya que raramente cobraban todos tras el proceso de liquidación. Lo real, y esto lo podemos comprobar no solo a nivel del Perú, es que a pesar de todos los esfuerzos legislativos y sanciones que han contemplado las diversas legislaciones en la materia, el derecho concursal no conseguía salvar ninguna empresa y los acreedores en la gran mayoría de los casos se sentían insatisfechos o sometidos a un procedimiento concursal en virtud del cual directa o indirectamente se encontraban forzados a lograr un acuerdo a efectos de poder recuperar en el mejor de los casos «algo» de lo que se les adeudaba.

Es necesario destacar que la nueva denominación de la legislación peruana relacionada con el derecho concursal hace referencia a una nueva filosofía respecto de los principios e intereses que inspiraba y pretendía proteger la legislación anterior. El nombre de «ley de Reestructuración Empresarial» implica que justamente el objetivo de la ley es la reestructuración empresarial antes que dirigirse directamente a la declaración de quiebra o la liquidación de la empresa. El hecho de que ley no se denomine «ley de Quiebras» o «ley de Liquidación de Empresas» nos indica que la idea de fondo es el intento de cambio en la filosofía del proceso. Es claro que la ley y el Estado no pueden forzar a los acreedores y deudores a llegar a un arreglo, ni a optar por la reestructuración, pero sí es posible que los mecanismos de la ley se dirijan a crear un marco de negociación entre deudores y acreedores para que se aplique un programa de salvación a la empresa antes de proceder a su liquidación o quiebra. En algunos países y cuando la crisis empresarial es muy seria, el Estado otorga incentivos a las empresas en dificultades para que los acreedores opten por el proyecto de reestructuración. Tal fue el caso de España con la ley de Reconversión Empresarial, que se ha analizado en la primera parte del trabajo. 
EI INDECOPI es el organismo competente, y a través de la Comisión de Simplificación de Acceso y Salida del Mercado deberá evaluar si es que procede declarar la insolvencia de la empresa analizando los créditos que van a ser puestos a cobro y/o los balances y demás información que deberá presentar el deudor. Estamos conscientes de que este análisis requiere de un alto grado de tecnificación para poder realmente evaluar el grado de insolvencia, como también requiere de un grado de tecnicismo el poder evaluar las alternativas de solución para reestructurar y salvar a las empresas en dificultades. Es por esto que una vez que la junta de acreedores se decida por esta opción que prevé la ley, deberá hacerse una evaluación técnica profunda por los nuevos administradores de la empresa para realmente exponer a la junta de acreedores la viabilidad del proyecto de salvación.

La nueva ley no está exenta de errores y probablemente la experiencia y aplicación de la misma nos hará notar la necesidad de implementar algunas modificaciones al cuerpo normativo; sin embargo, no por esto vamos a desconocer el mérito que de por sí ya tiene la elaboración y la promulgación de una ley que pretende implantar una nueva filosofía en el derecho concursal peruano para estar a tono con la tendencia actual en el mundo.

Hemos mencionado en este mismo artículo que el criterio objetivo para evaluar la deuda puede no ser el mejor, ya que 50 UITs de deuda podrá ser mucho o muy poco de acuerdo con el volumen de operaciones y el patrimonio de la empresa en dificultades. También tenemos inquietud en conocer cómo será el funcionamiento y cómo realizará su labor el INDECOPI a través de sus comisiones y los tribunales correspondientes respecto de las materias que le competen. Es sumamente importante que los miembros de las comisiones y del tribunal estén capacitados respecto de las áreas que son de su competencia, ya que por ejemplo para efectos de evaluar las posibilidades de reflotamiento de una empresa será necesario no solamente tener criterio jurídico sino aplicar conocimientos técnicos que permitan apreciar cuán posible es la alternativa de reestructuración porque efectivamente no toda empresa podrá ser reflotada. Si bien es cierto será importante apreciar la función del órgano jurisdiccional, el mismo que sólo podrá delegar sus funciones en entidades públicas o privadas de prestigio, con personal especializado y con experiencia comprobada en materia de legislación económica y financiera, el éxito de esta nueva ley podrá ser evaluado en función del número de empresas que se pueda salvar y en la medida en que los acreedores y deudores se encuentren satisfechos con estos mecanismos. 
Considero que es adecuada la eliminación de la figura del síndico de quiebra tal y como lo contemplaba la ley 7566, ya que la intervención de éste fue negativa en muchos casos debido a la corruptela a la que se prestaba la amplitud de las atribuciones, llegándose a un desprestigio paulatino de la función, promoviéndose en algunas oportunidades el remate indiscriminado y hasta subvaluado de los activos con el propósito egoísta de cobrar los honorarios sobre un porcentaje del valor de los bienes. En la ley de Reestructuración Empresarial se sustituye la figura del síndico por la del bando liquidador. Esta modificación, creemos, inspirará una mayor confianza en los acreedores. Pensamos que el sistema previsto en la ley atenúa la presión que sentían los acreedores con la legislación anterior en aceptar el convenio con la empresa deudora, la misma que imponía de algún modo los términos del «reflotamiento» a través de acuerdos extrajudiciales. Respecto de las Cámaras de Comercio, que eran las encargadas de auspiciar las situaciones «extrajudiciales», dejan de tener esa funcion a partir de la fecha; sin embargo, nada impide que el INDECOPI, en virtud de las atribuciones que la misma ley le concede, pueda celebrar convenios con las Cámaras de Comercio a efectos de hacerlas partícipes en esta nueva legislación.

Si tuviéramos que describir brevemente la evolución del derecho concursal en la historia, podríamos decir que un primer paso fue el de la evolución de un mecanismo de represión personal a un procedimiento de ejecución colectivo dirigido a la liquidación de empresas, para llegar hoy a un sistema que se esfuerza por rescatar el conjunto empresarial salvaguardando los diversos intereses comprometidos, intentando como principal alternativa el reflotamiento o reactivación.

\section{2 ¿Cuál es el tratamiento que se les debe dar a las em- presas con dificultades?}

Debemos ser conscientes de que el salvataje de la empresa no puede ser intentado sino bajo condición de que existan serias condiciones de éxito y perdurabilidad en el plano económico $0^{36}$, y para esto es necesario plantear dos situaciones: en primer lugar se encuentra la búsqueda de la solución y en segundo lugar su ejecución. Previa a la búsqueda de la solución es nece-

${ }^{36}$ Palllusseau, op. cit., p. 687. 
sario aplicar una pericia acerca de la viabilidad de la empresa, implementando y negociando la posibilidad de que la empresa sea reactivada.

Muchas veces la supervivencia de la empresa depende del cierre de determinados sectores de su actividad, o de la cesión de determinados elementos de su activo, del cambio de rubro de su actividad, etc. Cualquiera que sea la medida, ésta debe ser viable. Para que la empresa continúe deberá seguir gozando de los activos de que dispone, así como de la vigencia de determinados contratos, como los de licencia, alquiler, distribución, exclusividad, propiedad industrial, etc.

La dirección de la empresa es otro problema que afronta el derecho concursal: en la medida de lo posible, y siempre y cuando no haya habido una responsabilidad directa, los dirigentes de la empresa deben tratar de mantenerse a efectos de que continúen con el negocio, siempre que no sean ellos los causantes de la insolvencia.

Será necesario también realizar un análisis acerca de las nuevas inversiones que deberá efectivizar la empresa para hacer frente a la competencia. Es evidente que dentro del análisis de la empresa en su conjunto, y al considerar cuál es el valor de sus productos, el monto de la inversión requerida, la calidad de sus elementos de producción, su circuito de distribución, algunos de estos elementos tendrán fallas importantes, ya que de otra manera nunca hubiese caído la empresa en el estado en que se encuentra. Por ello es importante preguntarse, no si la empresa los tiene en ese momento actual sino si puede ser viable la empresa en un futuro gracias a la intervención externa. Este análisis implica investigación y opinión técnica, la que deberá ser realizada por auditores y especialistas en la materia.

La viabilidad acerca de la reestructuración y supervivencia de la empresa la deben determinar especialistas; no cualquier persona está en condiciones de evaluar todos los elementos técnicos que confluyen para determinar si el salvataje de una empresa es posible o no. No hay duda de que la supervivencia de la empresa exigirá cierto sacrificio por parte de los intereses en juego: el personal tendrá que soportar algunos despidos, los acreedores tal vez perjudiquen en algo sus créditos, los accionistas verán limitados sus derechos. Lo esencial es que estos sacrificios no serán en vano y que finalmente se obtenga una solución satisfactoria en el plano económico y financiero, que les permita estar en una mejor posición en el futuro. 
Las alternativas de supervivencia pueden ser varias y de distintos tipos: una podría ser el caso de sanear a la empresa bajo la misma forma jurídica, una segunda posibilidad sería transferir el goce de la empresa mediante un contrato de locación-gerencia y otra alternativa podría ser la transferencia de la propiedad de la empresa.

\subsection{El futuro y el presente}

En la legislación argentina, según Fernando Bosch y Emilio Perea en su artículo «La responsabilidad de los directores de las Sociedades Anónimas y de su adecuación al Derecho moderno", se advierte una tendencia a contemplar aquellos supuestos en que se utiliza a la sociedad para atender actitudes reñidas con la buena fe comercial, la moral y la licitud. Es así que se llega a responsabilizar solidaria e ilimitadamente a los directores, administradores, gerentes y representantes de la sociedad, cuando se acredite que su conducta ha sido dolosa o culposa en los términos que establece la ley ${ }^{37}$.

El artículo 165 de la ley de Concurso argentina vigente en el año 1976, disponía la posibilidad de extender la quiebra de la sociedad a toda persona que bajo la apariencia de la actuación de aquella, efectuara actos en su interés personal disponiendo de los bienes de la sociedad como si fueran propios, en fraude de los acreedores ${ }^{38}$. Puede que la adecuación de estas medidas que están relacionadas con el derecho concursal, los derechos económicos y el derecho societario (el levantamiento del velo societario, etc...), implique un cambio estructural de la sociedad anónima tradicional, ya que estarían de alguna manera contraviniendo el principio de la limitación de la responsabilidad para quienes integran el organo de la administracion. Pero no podemos negar el argumento de aquellos que afirman que al responsabilizar a aquellas personas físicas que tienen el efectivo control de la dirección de la sociedad, con una responsabilidad ilimitada, surge como consecuencia de ello una mayor cautela, un mayor celo y cuidado en el ejercicio de sus funciones, llegándose indirectamente a cuidar que se cumplan los ob-

${ }^{37}$ Bosch, Fernando y Perea, Emilio. «La responsabilidad de los directores de las Sociedades Anónimas y su adecuación al Derecho moderno», Revista de Derecho Comercial, 1976, p. 602.

38 Ibídem, p. 602. 
jetivos que, para el caso del Perú, señala el artículo 172 al disponer que el director deberá desempeñar el cargo con la diligencia de un ordenado comerciante y un representante leal.

Esta situación traería como consecuencia inmediata, no sólo que el empresario tenga un mayor cuidado respecto de la nominación de sus representantes en los directorios de las empresas, gerencias y apoderados, sino también que aquellos que acepten el cargo que se les confiere asimilen cuál es el grado de su responsabilidad, y de esta forma se estaría disuadiendo a los prestanombres y a los empresarios inescrupulosos.

Respecto de la teoría del levantamiento del velo societario, varias inquietudes podrán presentarse en nuestra mente, como por ejemplo: ¿podrá, en virtud de ésta, afectarse a empresas con negocios distintos al de la empresa en dificultades, pero que tienen accionariado y control común a través de una holding? ¿Y si existe fraude comprobado o si ha habido flujo de dinero de una a otra? ¿O si una empresa ha sido gerente de la otra?

Estos son temas que deberán analizarse con mayor detalle y en cuya solución la jurisprudencia debiera cumplir su rol de fuente de derecho.

Es curioso apreciar cómo, si bien la tendencia económica en el mundo es hacia un liberalismo claramente definido con matices que cada país aplica de acuerdo con sus propios intereses y/o políticas gubernamentales, sin embargo cada vez hay una mayor conciencia, atención y preocupación de la ley respecto del interés social. Una muestra de ello es no solamente los diversos intereses que podemos encontrar en el derecho concursal respecto del reflotamiento de una empresa, tales como el interés de los empleados, el interés de los acreedores, el interés de los proveedores, el interés del cliente, sino también lo que se puede apreciar en la legislación referida a la competencia desleal, al antitrust o leyes antimonopolios y a la protección de los derechos patrimoniales e industriales, con cada vez mayor cautela respecto de los intereses del consumidor y del público en general.

Creemos que la ley de Reestructuración Empresarial es un avance respecto de la legislación anterior de quiebra y creemos que incorpora de alguna manera, sin que esté exenta de vacíos y defectos (por ejemplo, nada dice la ley acerca de los garantes del deudor), que apreciaremos con mayor claridad en su aplicación. 
A futuro será necesario incorporar en la legislación nacional, no solamente en el ámbito del derecho concursal sino también en otras áreas, la instauración de procedimientos de alerta que parte de la doctrina postula, para efectos de prever con anticipación las situaciones dificultosas de las empresas. Qué duda cabe que necesitamos igualmente afinar los mecanismos de prevención y su efectivo control. La aplicación de la ley y la tarea que realiza el órgano jurisdiccional serán de suma importancia para poder evaluar cuáles son las modificaciones o adecuaciones necesarias para la debida aplicación de una ley de reestructuración empresarial que pretende adecuarse a las tendencias económicas, sociales y jurídicas de actualidad, a través de la cual es posible rescatar los valores intangibles de la empresa (know how, good will, etc.) que permitirán una mejor forma de pago a los acreedores, cautelándose además, con la supervivencia, los distintos intereses que confluyen en el caso de una empresa en dificultades. Una empresa liquidada sólo permite a unos cuantos recuperar su dinero, pero no satisface a todos los intereses involucrados y probablemente tampoco a la totalidad de los acreedores.

Casi con certeza podríamos afirmar que los legisladores y la doctrina están inclinándose claramente por tender a la conservación de la empresa y mantener el empleo aun en perjuicio de los acreedores. Estamos pasando del derecho de la quiebra al derecho de la crisis empresarial, como lo llama Beltrán, al derecho de las empresas en dificultades, como lo llamara Paillusseau, etc. Lo que hasta hace un tiempo en las legislaciones concursales del mundo era una alternativa excepcional, cual es el reflotamiento de la empresa frente a la solución tradicional de liquidación del patrimonio, será el día de hoy la alternativa normal, incluso la preferida del procedimiento concursal. 